\title{
Reemergence of human malaria in Atlantic Forest of Rio Grande do Sul, Brazil
}

\author{
Alessandra Bittencourt de Lemos ${ }^{1 /+}$, Onilda Santos da Silva ${ }^{1}$, Sandra Cristina Deboni ${ }^{2}$, \\ Valdir Schallemberger ${ }^{3}$, Edmilson dos Santos ${ }^{4}$, Marco Antônio Barreto de Almeida ${ }^{4}$, \\ Anne Andrea Dockhorn Marth ${ }^{5}$, Sidnei Silva ${ }^{6}$, Aline Rosa de Lavigne Mello ${ }^{7}$, \\ Teresa Fernandes Silva-do-Nascimento ${ }^{8}$, Maria de Fátima Ferreira-da-Cruz ${ }^{7}$, \\ Ricardo Lourenço-de-Oliveira ${ }^{8}$, Jáder da Cruz Cardoso ${ }^{4}+$
}

${ }^{1}$ Universidade Federal do Rio Grande do Sul, Departamento de Microbiologia, Imunologia e Parasitologia, Porto Alegre, RS, Brasil ${ }^{2}$ Secretaria da Saúde do Estado do Rio Grande do Sul, Centro Estadual de Vigilância em Saúde, Divisão de Vigilância Epidemiológica, Porto Alegre, RS, Brasil

${ }^{3}$ Secretaria da Saúde do Estado do Rio Grande do Sul, Centro Estadual de Vigilância em Saúde, Laboratório Central de Saúde Pública, Porto Alegre, RS, Brasil

${ }^{4}$ Secretaria da Saúde do Estado do Rio Grande do Sul, Centro Estadual de Vigilância em Saúde, Divisão de Vigilância Ambiental em Saúde, Porto Alegre, RS, Brasil

${ }^{5}$ Secretaria da Saúde do Estado do Rio Grande do Sul, 18ª Coordenadoria Regional de Saúde, Osório, RS, Brasil

${ }^{6}$ Fundação Oswaldo Cruz-Fiocruz, Instituto Nacional de Infectologia Evandro Chagas, Laboratório de Parasitologia, Rio de Janeiro, RJ, Brasil

${ }^{7}$ Fundação Oswaldo Cruz-Fiocruz, Instituto Oswaldo Cruz, Laboratório de Pesquisas em Malária, Rio de Janeiro, RJ, Brasil

${ }^{8}$ Fundação Oswaldo Cruz-Fiocruz, Instituto Oswaldo Cruz, Laboratório de Mosquitos Transmissores de Hematozoários, Rio de Janeiro, RJ, Brasil

Unforeseen Plasmodium infections in the Atlantic Forest of Brazilian Extra-Amazonian region could jeopardise malaria elimination. A human malaria case was registered in Três Forquilhas, in the Atlantic Forest biome of Rio Grande do Sul, after a 45 years' time-lapsed without any malaria autochthonous notification in this southern Brazilian state. This finding represents the expansion of the malaria distribution areas in Brazil and the southernmost human malaria case record in South America in this decade. The coexistence of the bromeliad-breeding vector Anopheles (Kerteszia) cruzii and non-human primates in the Atlantic Forest regularly visited by the patient claimed for the zoonotic origin of this infection. The reemergence of Atlantic Forest human malaria in Rio Grande do Sul was also discussed.

Key words: Anopheles - Plasmodium vivax - Plasmodium simium - malaria - Kerteszia

Malaria is an acute febrile infectious disease caused by Plasmodium parasites transmitted by infecting bites of anopheline female mosquitoes. Malaria affects thousands of people worldwide and, therefore, represents a serious public health problem, especially in populations of tropical and subtropical regions of Africa, Asia and Central and South Americas.(1) In 2019, about 89\% of malaria cases registered in Brazil were caused by Plasmodium vivax, while $P$. falciparum accounted for just over $10 \%$ of cases, and P. malariae was rarely diagnosed. ${ }^{(2)}$ In Brazil, there are two main epidemiological and transmission profiles: (i) the Amazon basin rainforest malaria, which accounts for more than $99 \%$ of the reported malaria cases and (ii) Atlantic Forest malaria that, despite accounting for only $0.08 \%$ of cases, complicates control measures and represents an important

doi: 10.1590/0074-02760210064

+ Corresponding authors: aleblemos2@gmail.com / jader-cardoso@saude.rs.gov.br

(D) https://orcid.org/0000-0001-6554-2861

(D) http://orcid.org/0000-0002-1214-1084

Received 01 March 2021

Accepted 11 June 2021 public health problem because of the case-fatality rate, due to the increased time elapsed for the diagnosis..$^{(2,3)}$ Differently from the Amazonian Region, where Anopheles (Nyssorhynchus) darlingi is responsible for the bulk of the endemic and epidemic transmission, Anopheles (Kerteszia) cruzii has been considered the main vector in the Atlantic Forest, a biome rich in bromeliads, the larval habitat of Kerteszia mosquitoes. ${ }^{(4)}$ Coincidently, An. cru$z i i$ is also the main vector of simian malaria in Atlantic Forest areas. ${ }^{(4,5)}$ In certain circumstances, the bites of $A n$. cruzii may be numerous both at the tree canopies and on ground level, and a high prevalence of both human and simian malaria would be expected. ${ }^{(4,6,7,8)}$

Rio Grande do Sul is the southernmost Brazilian State. The first records of malaria in this state date back to 1900 in a port city named Rio Grande, located in the southern state coast. ${ }^{(9)}$ In 1918, the disease was recorded at the northern coast, in the municipality of Torres, bordering the State of Santa Catarina. ${ }^{(10,11)}$ Thereafter, the northern coastal zone between the municipalities of Torres and Osório, essentially from latitude $29^{\circ} 30^{\prime}$ to $29^{\circ} 59^{\prime}$, was considered the hot spot malaria transmission area until the end of the 1960s. After several control actions, autochthonous human malaria was no longer recorded in Rio Grande do Sul..$^{(12,13,14,15,16)}$ Then, after more than four decades, an unexpected malaria case was detected in April 2014, in a 58-year-old white male, diabetic insulin 
dependent, living in the anopheline-free urban area of Terra de Areia (29 $35^{\prime} 13^{\prime}$ 'S $50^{\circ} 03^{\prime} 59^{\prime}$ 'W), a municipality at the northern coastal zone distant $45 \mathrm{~km}$ from Torres and $122 \mathrm{~km}$ from Porto Alegre, the capital of Rio Grande do Sul (Fig. 1). Even though the patient lives in an urban area, he often spent the weekends and holidays in his vacation home at the rural area of the Três Forquilhas municipality (site $1-29^{\circ} 22^{\prime} 56.1^{\prime \prime} \mathrm{S} 50^{\circ} 10^{\prime} 03.6^{\prime \prime} \mathrm{W}$ ) and hunting in the vicinity woods of his employee's lands (site 2 - 29 $23^{\prime} 59.43^{\prime \prime S} 50^{\circ} 07^{\prime} 54.46^{\prime \prime} \mathrm{W}$ ) (Fig. 1). Both 1 and 2 sites are located in the Atlantic Forest biome (Fig. 2). At the onset of the symptoms, the patient reported cough, runny nose and body aches on April 24th. After seven days, symptoms progressed to fever, sweating, chills, dyspnea and intense tremors. On May 11, and after 10 days of treatment for a suspected leptospirosis, the patient was admitted to the Intensive Care Unit of São Lucas Hospital in Porto Alegre, where his clinical features progressed to renal failure, thrombocytopenia and disorientation. Promptly, the blood film examination detected the presence of Plasmodium and the protocol treatment for severe and complicated malaria, recommended by the Brazilian Ministry of Health, was started. (17) The next day, after notification to the Epidemiological Surveillance of Porto Alegre municipality, thin blood smears were forwarded to the Parasitology Laboratory of the Central Laboratory of the State Department of Health of Rio Grande do Sul - LACEN/SES-RS, where $P$. vivax malaria infection was diagnosed with a parasitaemia of 5,000 parasites $/ \mu \mathrm{L}$. The patient recovered and left the hospital on May 20th.

Concomitantly, according to the recommendations of the Brazilian Ministry of Health, a patient blood sample taken during hospitalisation was sent to the Extra-Amazon Reference Centre for Malaria Diagnosis, at Fundação Oswaldo Cruz, for confirmation of malaria diagnosis by parasitological and molecular methodologies and to rule out the possibility of co-infection by polymerase chain reaction (PCR). For this end, the genomic DNA was extracted from $1 \mathrm{~mL}$ whole blood using QIAamp

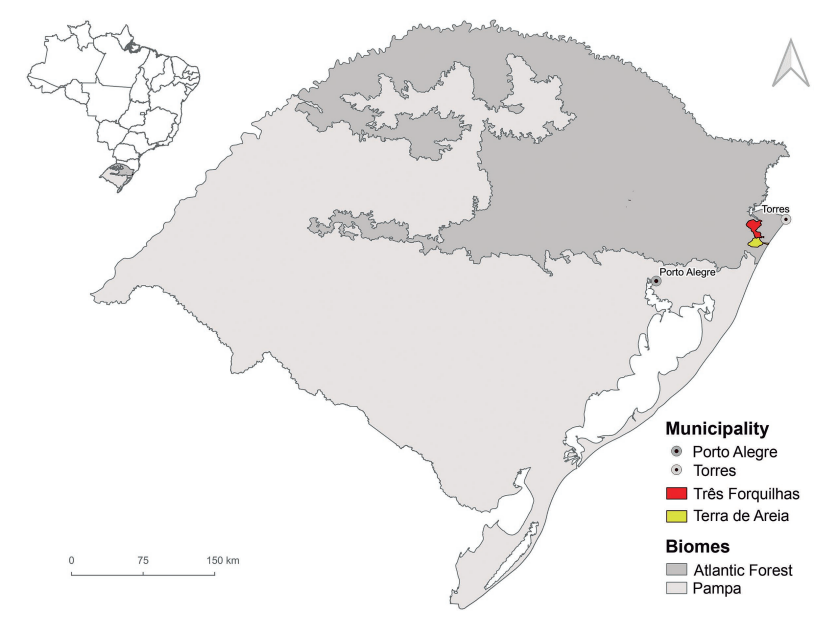

Fig. 1: Rio Grande do Sul State, highlighting the Três Forquilhas and Terra de Areia municipalities, in the Atlantic Forest Biome. midi columns, as described by the manufacturer (Qia$\left.\operatorname{gen}^{\circledR}\right)$. P. simium/P. vivax was diagnosed by convention$\mathrm{al}^{(18)}$ and real-time ${ }^{(19)}$ PCRs, and no P. falciparum or $P$. malariae infection was detected; ${ }^{(20,21)}$ the same was true for microscopic examination.

To identify vectors possibly involved in the transmission, in November 17 and 19, 2014, a team from the Environmental Health Surveillance (CEVS) collected mosquitoes in site 2, (Fig. 3) using Shannon trap between 6:30 - 9:30PM. Mosquitoes were sent to the Laboratory of Mosquitoes and Hematozoa Transmitters (LATHEMA) of Fundação Oswaldo Cruz and 268 specimens of Anopheles (Kerteszia) cruzii were identified. Aiming to identify Plasmodium infection in these samples, entire bodies of mosquitoes were polled ( $\leq 5$ individuals each) and homogenised in $50 \mu \mathrm{L}$ of DNA-free sterile distilled water by using the Precellys $24^{\circledR}$ tissue homogeniser in bead tubes. DNAzol $(150 \mu \mathrm{L})$ was added to the homogenates, following centrifugation ( $9600 \mathrm{x} \mathrm{g}, 10 \mathrm{~min})$. DNA was extracted from $160 \mu \mathrm{L}$ of supernatant after precipitation with $100 \mu \mathrm{L}$ of $100 \%$ ethanol, following centrifugation $(9600 \mathrm{x} g, 10 \mathrm{~min})$. The pellet was resuspended with $160 \mu \mathrm{L}$ of $70 \%$ ethanol and subsequently centrifuged as above. After evaporation at room temperature, the pellet was finally resuspended in $40 \mu \mathrm{L}$ of DNA-free sterile distilled water and incubated at $4^{\circ} \mathrm{C}$ overnight. Then, PCR was performed employing the same protocols used for detection of the human malaria infection. All mosquitoes tested negative for $P$. falciparum, $P$. vivax and $P$. malariae infections.

The epidemiological investigation did not detect any introduced or imported malaria case either in the municipality where the patient lives (Terra de Areia, an urban area) or in the municipality regularly visited by the patient (Três Forquilhas). In addition, the patient did not report any travel to Brazilian or foreign malaria endemic areas and did not receive a blood transfusion. All these data, plus the capture of An. cruzii in Três Forquilhas, as well as the presence of howler monkeys, the main reservoir of malaria parasites-infecting humans ${ }^{(5,7,22,23)}$ in Atlantic Forest sites visited by the patient, strongly points to Três Forquilhas as the infection site and raised the hypothesis of a zoonotic malaria. Indeed, simian parasites originating tertian malaria human outbreaks have been reported in Atlantic Forest of Southeast Brazil ${ }^{(23)}$ and, in the same way, the vast majority of malaria cases consisted of people living in urban areas who went to Atlantic Forest for leisure. It is well known that two simian Plasmodium species infecting-humans occur in South America: P. simium and P. brasilianum. P. brasilianum and $P$. malariae are considered the same species ${ }^{(24)}$ and the parasite is conventionally called $P$. brasilianum when detected in monkeys and $P$. malariae when diagnosed in humans. P. simium has a high degree of morphological, genetic, and immunologic similarities with $P$. vivax ${ }^{(25,26)}$ and, therefore, it is possible to detect this parasite using in house $P$. vivax PCRs, as used in this work. While $P$. brasilianum is spread in the South America continent and has been found infecting several non-human primate species, $P$. simium has only been found in southern and southeastern Brazilian Atlantic Forest biome and infect- 


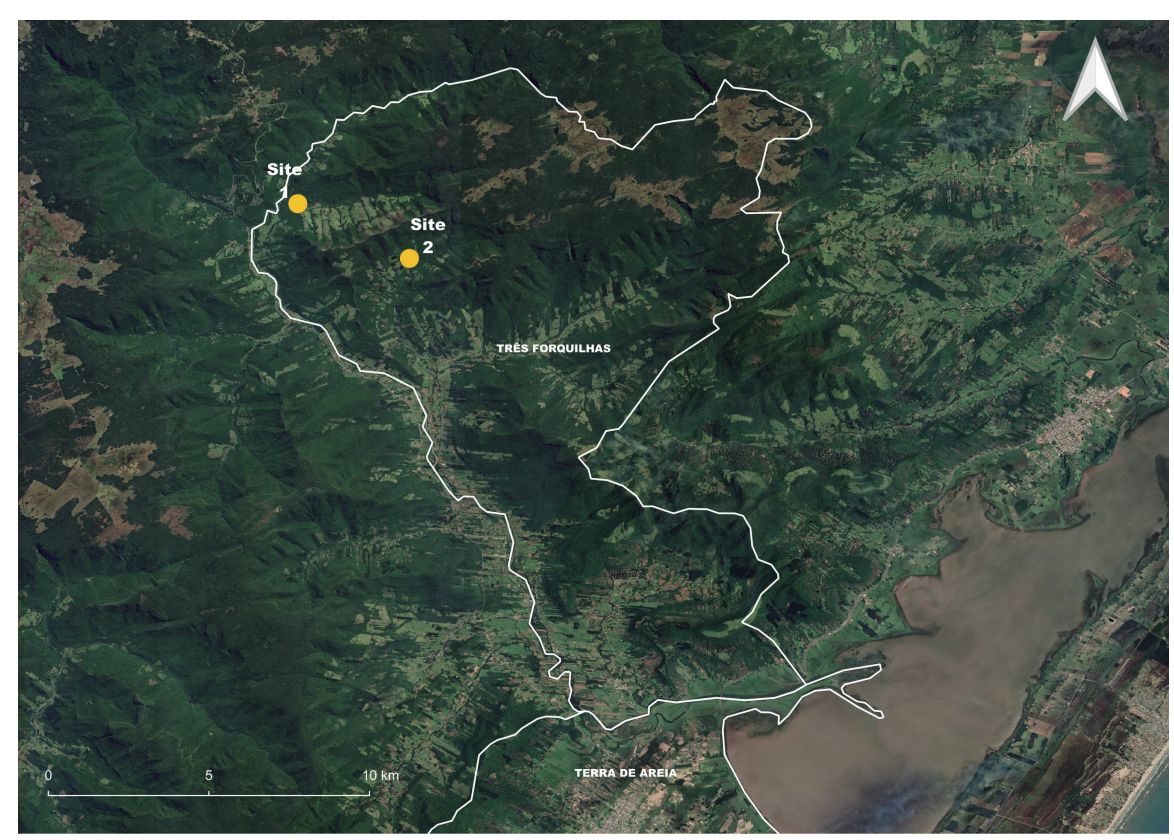

Fig. 2: location of the areas visited by the malaria patient in forest environments of the municipality of Três Forquilhas. Site 1) Patient vacation home; Site 2) Patient's employee lands.
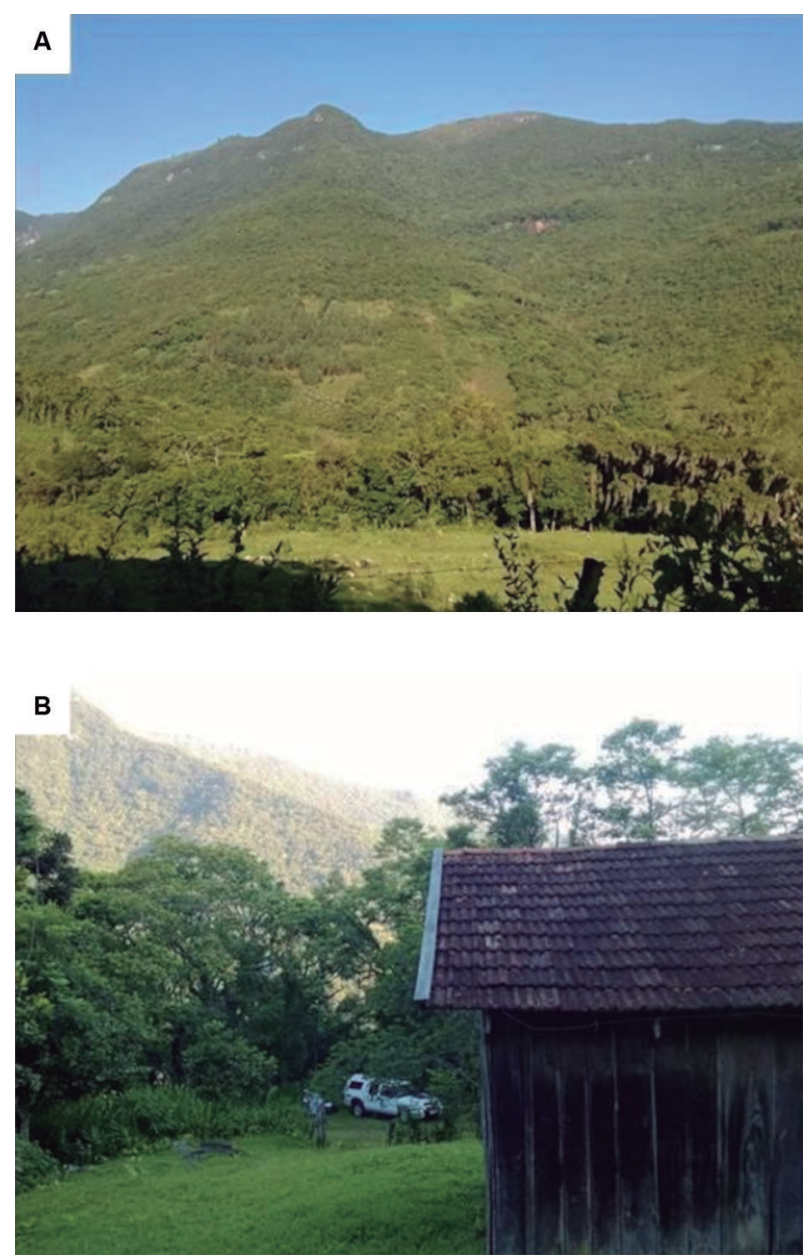

Fig. 3: probable infection site, in the municipality of Três Forquilhas. (A) Landscape profile of the region; (B) Patient employee's lands.

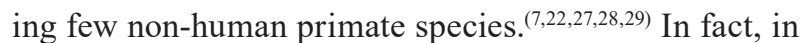
1969, when Rio Grande do Sul was already considered a human malaria-free area, $P$. simium was detected in $\mathrm{Al}$ ouatta guariba clamitans (red-howler monkey) from the metropolitan region of Porto Alegre. ${ }^{(30)}$ More recently, $P$. simium has also been recorded in the same non-human primate species from two other Rio Grande do Sul municipalities: in 2003, in a blood sample of a free-living ill animal at the State Park of Itapuã, in the municipality of Viamão ${ }^{(31)}$ and in 2017, in captive animals, from the municipality of Morro Reuter, ${ }^{(32)}$ respectively, 135 to 90 $\mathrm{km}$ away from Três Forquilhas where the malaria case here reported occurred. Interesting, the only anopheline species found in the sites visited by the patient was $A n$. cruzii, a neotropical, exophilic and opportunistic blood feed species that may bite non-human primate at the canopy of trees, and humans at the ground level in the forest and surroundings capable to transmit, therefore, zoonotic malaria of simian origin. ${ }^{(4,5,33)}$ This mosquito vector breeds in water hold in bromeliads and thus, the malaria it disseminates is called "bromeliad malaria" and is usually transmitted outdoors to people working or living in close contact or visiting this ambient for leisure activities, ${ }^{(7,23)}$ as happened with the Rio Grande do Sul malaria case here reported.

Because of the lack of detection of human malaria throughout Rio Grande do Sul for more than four decades, the malaria case here reported was much probably detected only due its severity requiring hospitalisation. Since no $P$. falciparum co-infection was disclosed, this unusual severity clinical manifestation could be related to preexisting comorbidity (diabetes) associated with the delay of the diagnosis, since the signs and symptoms of human malaria infections originating from non-human primates in the Atlantic Forest are usually mild to moderate. ${ }^{(34)}$ 
The malaria case here reported showed the reemergence of human malaria in the southernmost Brazil as well as in South America as a whole, since countries with territories of similar or lower latitudes (Uruguay, Chile and Argentina) have been considered malaria free areas for two decades now. ${ }^{(35)}$

In Rio Grande do Sul, as in other Brazilian areas of extra-Amazonia, the large-time gap with no malaria case detection certainly contribute to rule out the possibility of malaria infection in febrile patients. Therefore, health units of the Rio Grande do Sul municipalities surrounding Atlantic Forest biome should include malaria as a differential diagnosis, and surveillance network of these regions must be attentive to febrile patients seeking care at health centers, aiming to improve the diagnosis and timely treatment cases. Finally, studies on the natural infection of Plasmodium species in non-human primates and Anopheles (Kerteszia) mosquitoes as well as serological surveys should be performed as eco-epidemiological surveillance strategies for identification of Atlantic Forest biome malaria transmission sites in Southern Brazil.

\section{ACKNOWLEDGEMENTS}

To the technicians of Epidemiological Surveillance of Porto Alegre municipality and Hospital São Lucas of PUCRS, who contributed to the detection and timely treatment of the patient. To Paulo Renato da Silva Abbad (DVAS/ CEVS) for elaborate the maps, and Roberto Peres (LATHEMA) for technical support.

\section{AUTHORS' CONTRIBUTION}

ABL and JCC conceived and designed the study; SD, AM, ES, MABA and JCC conducted the eco-epidemiological investigations in the municipalities of Terra de Areia and Três Forquilhas; VS identified and SS confirmed the parasitological diagnosis in the patient blood films; MFFC and ARLM extracted human DNA and performed human and mosquito molecular diagnosis; RLO and TFSN performed mosquitos' taxonomic identification and extracted mosquitoes DNA for molecular diagnosis; ABL, OSS, RLO, MFFC and JCC wrote the manuscript. All authors read, made suggestions and approved the final version of the manuscript.

\section{REFERENCES}

1. Phillips MA, Burrows JN, Manyando C, Van Huijsduijnen RF, Van Voorhis WC, Wells TNC, et al. Malaria. Nat Rev Dis Primers. 2017; 3(17050).

2. MS/SVS - Ministério da Saúde/Secretaria de Vigilância em Saúde. Malária 2020. Boletim Epidemiológico. Número especial. Brasília: MS/SVS; 2020. 118 pp.

3. de Pina-Costa A, Brasil P, Di Santi SM, de Araujo MP, Suárez-Mutis MC, Santelli ACFS, et al. Malaria in Brazil: what happens outside the Amazonian endemic region. Mem Inst Oswaldo Cruz. 2014; 109(5): 618-34.

4. Deane LM. Malaria vectors in Brazil. Mem Inst Oswaldo Cruz. 1986; 81(Suppl. 2): 5-14.

5. Deane LM, Ferreira Neto JA, Deane MP, Silveira IP. Anopheles (Kerteszia) cruzii, a natural vector of the monkey malaria parasites, Plasmodium simium and Plasmodium brasilianum. Trans R Soc Trop Med Hyg. 1970; 64(4): 647.
6. Medeiros-Sousa AR, de Oliveira Christe R, Duarte AMRC, Mucci LF, Ceretti-Junior W, Marrelli MT. Effects of anthropogenic landscape changes on the abundance and acrodendrophily of Anopheles (Kerteszia) cruzii, the main vector of malaria parasites in the Atlantic Forest in Brazil. Malar J. 2019; 18: 110.

7. Deane LM. Malaria studies and control in Brazil. Am J Trop Med Hyg. 1988; 38(2): 223-30.

8. Multini LC, Marrelli MT, Beier JC, Wilke ABB. Increasing complexity threatens the elimination of extra-Amazonian Malaria in Brazil. Trends Parasitol. 2019; 35: 383-7.

9. Dourado A. O impaludismo no Rio Grande do Sul. Rio Grande: Typographia da Livraria Rio-Grandense; 1900. 55 pp.

10. Machado LS. A malária no Rio Grande do Sul. In Faillace JM, editor. Arquivos do Departamento Estadual de Saúde - Rio Grande do Sul. Porto Alegre: 1943. p. 83-5.

11. Machado LS. O paludismo do Rio Grande do Sul. In: Franco A, Ramos SM, editors. Panteão médico riograndense: síntese cultural e histórica: progresso e evolução da medicina no Estado do Rio Grande do Sul. São Paulo: Ramos, Franco Ed; 1943. p. 169-70.

12. di Primio R. O impaludismo autoctone do Rio Grande do Sul. Arquivos Rio Grandenses de Medicina. 1931; 10(4): 1-6.

13. di Primio R. A espécie dominante do Plasmódio, na zona endemo-epidemica de malaria no Rio Grande do Sul. Arquivos Rio Grandenses de Medicina. 1933; 12(4): 197-8.

14. di Primio R. Impaludismo e anofelinas do Rio Grande do Sul. Arquivos Rio Grandenses de Medicina. 1938; 6: 271-99.

15. Barata JMS. Estado atual da bromélia-malária no Brasil [monograph] [internet]. São Paulo: Faculdade de Saúde Pública da Universidade de São Paulo; 1973 [cited in 22 feb 2021]. Available from: teses.usp.br/teses/disponiveis/6/6132/tde-17102016-161321/ publico/MTR_152_Barata_1973.pdf.

16. Moreira DL, Cardoso JC, Deboni SC, Falci DR. Malaria in Southern Brazil: a potential threat for a non-endemic region. Braz J Infect Dis. 2017; 21(6): 678-9.

17. MS/SVS - Ministério da Saúde/Secretaria de Vigilância em Saúde/Departamento de Imunização e Doenças Transmissíveis. Guia prático de tratamento da malária no Brasil. Brasília: Ministério da Saúde. 2010; 36 pp.

18. Torres KL, Figueiredo DV, Zalis MG, Daniel-Ribeiro CT, Alecrim W, Ferreira-da-Cruz MF. Standardization of a very specific and sensitive single PCR for detection of Plasmodium vivax in low parasitized individuals and its usefulness for screening blood donors. Parasitol Res. 2006; 98(6): 519-24.

19. Almeida-de-Oliveira NK, Moreira OC, de Lavigne AR, Mendonça-Lima L, Werneck GL, Daniel-Ribeiro CT, et al. Analytical validation of real-time quantitative PCR assays for optimum diagnosis of vivax malaria. Mem Inst Oswaldo Cruz. 2019; 114: e180350.

20. Zalis MG, Ferreira-da-Cruz MF, Balthazar-Guedes HC, Banic DM, Alecrim W, Souza JM, et al. Malaria diagnosis: standardization of a polymerase chain reaction for the detection of Plasmodium falciparum parasites in individuals with low-grade parasitemia. Parasitol Res. 1996; 82(7): 612-6.

21. Snounou G, Singh B. Nested PCR analysis of Plasmodium parasites. Methods Mol Med. 2002; 72: 189-203.

22. de Abreu FVS, dos Santos E, Mello ARL, Gomes LR, de Alvarenga DAM, Gomes MQ, et al. Howler monkeys are the reservoir of malarial parasites causing zoonotic infections in the Atlantic Forest of Rio de Janeiro. PLoS Negl Trop Dis. 2019; 13(12): e0007906. 
23. Brasil P, Zalis MG, Pina-Costa A, Siqueira AM, Bianco Jr C, Silva $\mathrm{S}$, et al. Outbreak of human malaria caused by Plasmodium simium in the Atlantic Forest in Rio de Janeiro: a molecular epidemiological investigation. Lancet Glob Health. 2017; 5: e1038-46.

24. Alvarenga DAM, Pina-Costa A, Bianco Jr C, Moreira SB, Brasil P, Pissinatti A, et al. New potential Plasmodium brasilianum hosts: tamarin and marmoset monkeys (family Callitrichidae). Malar J. 2017; 16(71): 1-7.

25. Lim CS, Tazi L, Ayala FJ. Plasmodium vivax: recent world expansion and genetic identity to Plasmodium simium. Proc Natl Acad Sci. 2005; 102: 15523-8.

26. Mourier T, de Alvarenga DAM, Kaushik A, Pina-Costa A, Guzmán-Vega FJ, Douvropoulou O, et al. The genome of the zoonotic malaria parasite Plasmodium simium reveals adaptions to host-switching. BioRxiv 841171 [Preprint]. 2019. Available from: https://www.biorxiv.org/content/10.1101/841171v2.full.pdf. Accessed 19 January 2021.

27. Lourenço-de-Oliveira RL, Deane LM. Simian malaria at two sites in the Brazilian Amazon. I - The infection rates of Plasmodium brasilianum in non-human primates. Mem Inst Oswaldo Cruz. 1995; 90(3): 331-9.

28. Duarte AMRC, Malafronte RS, Cerutti Jr C, Curado I, de Paiva BR, Maeda AY, et al. Natural Plasmodium infections in Brazilian wild monkeys: reservoirs for human infections? Acta Trop. 2008; 107: 179-85.

29. de Alvarenga DAM, de Pina-Costa A, de Sousa TN, Pissinatti A, Zalis MG, Suaréz-Mutis MC, et al. Simian malaria in the Brazilian
Atlantic Forest: first description of natural infection of capuchin monkeys (Cebinae subfamily) by Plasmodium simium. Malar J. 2015; 14(81): 1-9.

30. Deane LM, Ferreira Neto JA. Malária em macacos do estado do Rio Grande do Sul. Observações preliminares. Rev Inst Med Trop São Paulo. 1969; 11(5): 299-305.

31. Duarte AMRC, Maeda AY, Torres MAN, dos Santos E, Fonseca DF, de Almeida MAB, et al. Infecção malárica em Bugio do Parque Estadual de Itapuã, Viamão, Rio Grande do Sul. Rev Patol Trop. 2005; 34.

32. Wink FF, Nunes NJS, Zafalon-silva B, Costa PM, Alievi MM, Valle SF, et al. Ocorrência de Plasmodium spp. em Bugio-ruivo (Alouatta guariba clamitans): relato de caso. Anais do II Encontro Brasileiro de Protozoologia Veterinária (EBPV) [internet]. 2017 [cited in 12 aug 2020]. Available from: http://www.uel.br/eventos/ebpv/pages/ arquivos/anais-\%20P\%C3\%B4ster\%20VEOU-\%20SITE.pdf.

33. Consoli RAGB, Lourenço-de-Oliveira R. Principais mosquitos de importância sanitária no Brasil. Rio de Janeiro: Fiocruz; 1994. 228 pp.

34. Buery JC, de Alencar FEC, Duarte AMRC, Loss AC, Vicente $\mathrm{CR}$, Ferreira LC, et al. Atlantic Forest malaria: a review of more than 20 years of epidemiological investigation. Microorganisms. 2021; 9(1): 132.

35. WHO - World Health Organization. World Malaria Report 2019 [internet]. 2019 [cited in 01 feb 2021]. Available from: https:// www.who.int/publications-detail/world-malaria-report-2019. 